\title{
Editorial
}

\section{Similarities among differences!}

\author{
Carlos Renato Zacharias \\ Editor-in-Chief, International Journal of High Dilution Research, IJHDR
}

Some time ago I read an article entitled "Small differences", published by Nature [1] whose author (Chris Tourney) pointed out some differences between nanotechnology and homeopathy. My first reaction was fear, because a text about homeopathy in Nature immediately brought me back to the "memory of water affair" with its entire context, polemics and scarring. But also surprise, since I had never before heard of homeopathy as an application of nanontechnology. The author was impartial in his presentation of homeopathy's principles and the comparison with nanomedicine. Furthermore, since his tone was direct and polite, it was not needed to dive too deep in analysis in order to conclude that medical nanoparticles have no relation to homeopathy.

At that time I did not understand Nature's reasons to publish that article, especially because its explicit premise was false, namely, that homeopathy can be compared to nanomedicine, as the author himself stated: "nanomedicine and homeopathy both involve very small amounts of material, but that is where the similarity ends". My first reaction was to pass over this article, but for a subconscious reason I cannot explain, I left it in the "to-do tray" of my computer. And indeed, one year later I could not let it go, so I thought better to read it attentively before deleting it once and for all from my archives.

And thus, I was able to detect deeper motives lying behind the apparently obvious text. Nanotechnology is one of the top-of-the-wave subjects in current science and technology. It is both significant and highly fashionable to work with nanodevices, nanostructures, nanosolutions... Nanoscience is truly a very wide field! Being so, why would anyone think on correlating it with homeopathy?

To remind, there is still no plausible explanation for the biological evidence of the effects of high dilutions and homeopathy. As many authors have declared with different expressions, the "art of cure" is running satisfactorily well whereas the "science of cure" is still crawling. The science of high dilution is still an emergent field of research requiring strict definitions of boundaries, concepts, models, reasoning and explanations. For this reason, each and every attempt at understanding such unconventional phenomena are valid, as long as they employ rigorous methods in observing, measuring, describing and recording their properties and consistent models of analysis leading to valid conclusions. Therefore, it is almost natural that many models have been applied for this goal, as e.g. quantum mechanics, non-equilibrium thermodynamics, dynamic systems models and ... nanoscience.

As I have stated in several opportunities in these editorials [2-5], it is the search for creative explanations to extraordinary experimental or theoretical data that pushes science forwards. However, with the proviso that scientific standards of practice are strictly taken into account and more particularly whenever already sanctioned concepts are challenged. Shortly, this, I suspect, was the reason behind the author's and the editor's decision to publish the article mentioned at the beginning.

In their zeal to explain the biological action of high dilutions, many authors trespass the domain of validity of some concepts, sometimes sounding dilettante. Quantum mechanics is not intellectual entertainment, but one 
of the engines behind the development of technology in the $20^{\text {th }}$ century. Dynamic systems are not a mathematical way to produce beautiful pictures but a powerful tool to preview global climate changes. Analogy and conceptual transposition can be useful to open our mind and teach us different ways of reasoning, but their limits must be observed and respected. On the other hand, research in high dilutions has its own specificities, and this also must be systematically taken into account.

All in all, in the end I do understand and furthermore, agree with Tourney when he calls on to avoid confounding matters, "Nanomedicine [...] is an exciting field for which researchers are justifiably optimistic. It is also a remarkably challenging field, as scientists, physicians and engineers attempt to navigate the biochemical intricacies of the human body. To see its strengths and weakness clearly, it is important that we do not confuse it with another field of theory or practice".

If one replaces the word "nanomedicine" by "high dilution" this conclusion also holds, but for "scale factor", namely the number of researchers and institutions involved and the amount of resources available to each field. I still believe that the minimization of these differences is a matter of time, and not of grounds, and that sooner or later they will be placed in equal footing.

While I am not an expert in the history of science, I have read and heard many times that Max Planck proposed quantization of energy as a "desperate attempt" to explain the experimental results of thermal emission of blackbody radiators [6]. This is how quantum mechanics was born! Planck and other scientists must have exhausted the resources of contemporary science in their attempts at explaining that unconventional phenomenon of emission of light. Many competing theories must have been proposed to explain the experimental data, some of them interesting, others more limited and a further group untenable. However, such a diversity of ideas must have been highly influential to stimulate debate, refine concepts, and open new possibilities. It is common knowledge that only the accepted theories make history while the defeated ones are left aside and erased from the syllabus of education in the sciences. This is to say, the new generations of scientists only learn about the manifest successes of science. Subliminally, they are also taught that a serious researcher never opposes the mainstream of "progress". And what is the greatest danger, they learn not to doubt the mainstream, even when it shows slight errors or anomalies that cannot be explained. Students then become partially blind researches, who cannot see past some boundaries, and feel threatened, instead of encouraged, by unusual phenomena and models.

In emergent fields, be nanoscience or high dilutions research, supports and skeptics have both an important role to play towards the all-important goal of doing good science in order to make the world a better place. And this is not a political or ideological war, but the mission of genuine science. A dogmatic or prejudiced researcher, be a supporter or a skeptic, will not accomplish his or her task.

Yes, Mr Tourney, nanomedicine and high dilution cannot be confused because they are really different! But maybe, not at all!!

\section{References}

[1] Tourney C, Nature Nanotechnology. 2009 May; vol 4: p275

[2] Zacharias CR. Publishing: why and whom to? [editorial]. Int J High Dilution Res [online]. 2008 [cited 2010 June 15]; 7(22): 1-2. Available from: http://www.feg.unesp.br/ ojs/index.php/ijhdr/article/view/263/323.

[3] Zacharias CR. The High Dilution phenomenon, Yours to Discover. [editorial]. Int J High Dilution Res [online]. 2009 [cited 2010 June 15]; 8(26): 1-2. Available from: http://www.feg.unesp.br/ ojs/index.php/ijhdr/article/view/331/378. 
[4] Zacharias CR. Where we are going to? [editorial]. Int J High Dilution Res [online]. 2009 [cited 2010 June 15]; 8(28): 80-81. Available from: http://www.feg.unesp.br/ ojs/index.php/ijhdr/article/view/355/398.

[5] Zacharias CR. "Mirror, mirror on the wall, who in the land is the wisest of all?" [editorial]. Int J High Dilution Res [online]. 2010 [cited 2010 June 15]; 9(30): 1-2. Available from: http://www.feg.unesp.br/ ojs/index.php/ijhdr/article/view/382/418

[6] Brandes T. The Radiation Laws and the Birth of Quantum Mechanics; [cited 2010 June 10]. Available from: http://wwwitp.physik.tu-berlin.de/brandes/public_html/qm/umist_qm/node3.html.

\section{(cc)) EY-NC-ND Licensed to GIRI}

How to cite this article: Zacharias CR. Similarities among differences! [editorial]. Int J High Dilution Res [online]. 2010 [cited YYYY Month dd]; 9(31): 58-60. Available from: http://www.feg.unesp.br/ ojs/index.php/ijhdr/article/view/401/437 